\title{
Research Article \\ Efficiency on the Use of Radiation and Corn Yield under Three Densities of Sowing
}

\author{
A. Morales-Ruiz, ${ }^{1}$ J. M. Loeza-Corte, ${ }^{1,2}$ E. Díaz-López, ${ }^{1}$ E. J. Morales-Rosales, ${ }^{3}$ \\ O. Franco-Mora, ${ }^{3}$ M. D. Mariezcurrena-Berasaín, ${ }^{3}$ and G. Estrada-Campuzano ${ }^{3}$ \\ ${ }^{1}$ Ingeniería en Agricultura Sustentable y Protegida, Universidad Tecnológica de Tehuacán, \\ Prolongación de la 1 sur No. 1101 San Pablo Tepetzingo, 75859 Tehuacán, PUE, Mexico \\ ${ }^{2}$ Ingeniería en Agroindustrias, Universidad de la Cañada, Carretera Teotitlán, \\ San Antonio km 1.7, Paraje Titlacuatitla, 68540 Teotitlán de Flores Magón, OAX, Mexico \\ ${ }^{3}$ Centro de Investigación y Estudios Avanzados en Fitomejoramiento, Universidad Autónoma del Estado de México, \\ Campus Universitario El Cerrillo Piedras Blancas, 50200 Toluca, MEX, Mexico
}

Correspondence should be addressed to A. Morales-Ruiz; alejandro.morales@uttehuacan.edu.mx

Received 9 November 2015; Revised 8 February 2016; Accepted 10 February 2016

Academic Editor: Silvia Imhoff

Copyright (C) 2016 A. Morales-Ruiz et al. This is an open access article distributed under the Creative Commons Attribution License, which permits unrestricted use, distribution, and reproduction in any medium, provided the original work is properly cited.

\begin{abstract}
Aiming to evaluate sowing densities and efficiency of radiation use, six corn genotypes, three from open pollination ("Amarillo Almoloya," "Cacahuacintle," and "Tiquipilco") and three hybrids ("Z-60," "Condor," and "H-50"), were sown at densities of 6.9, 7.8, and 8.9 plants $\mathrm{m}^{-2}$, under a split plot design, within a factorial arrangement of treatments during three years (2008, 2009, and 2010). Evaluated variables were yield, harvest index, biomass production, attenuation coefficient, and radiation use efficiency. Results indicate that 2008 was the best year because yield, biomass, and radiation use efficiency were $1132.6,3505 \mathrm{gm}^{-2}$, and $0.79 \mathrm{~g} \mathrm{MJ}^{-1}$, respectively. "Jiquipilco" was the genotype that exhibited the best adaptability to climatic conditions of the zone; thus, it is recommended to be grown on the studied zone.
\end{abstract}

\section{Introduction}

The maize (Zea mays L.) is of family Gramineae domesticated by indigenous cultures in Mesoamerica region, particularly in the Tehuacan-Cuicatlan Valley in Mexico [1]. It is considered a staple crop on human diet because it supplies carbohydrates needed to obtain metabolic energy. It is also used to grow huitlacoche gall that is used for human consumption [2, 3]. Among environmental factors that affect yield significantly, we may cite solar radiation that interacts with water absorption, nutrients, and temperature [4], influencing the photosynthesis process, which, in turn, determines biomass accumulation on crops; this has been corroborated by [5] who mentioned that solar radiation is a key to determine the plant growth factor. Factors that affect this process are solar light interception and utilization, through crop canopy structure, to transform light in photo assimilates and to transfer carbohydrates to demanding organs [6]. For corn production, dry matter accumulation is one of the more important yield components and this, in turn, is the result of interception and use of the incident solar radiation on the foliage structure of the crop during the growing cycle [7]. To increase grain yield on corn, it is important to increase the amount of intercepted radiation that depends on the variety, sowing density, sowing date, and stage of development [8]. To reach high levels of intercepted radiation, the development of a high leaf area index since early growth stages [9] is needed. An optimum leaf area index (LAI) is the one that allows the maximum dry biomass production, and this is reached when lower canopy leaves maintain a positive balance of carbon; this means when the crop absorbs the whole photosynthetically active radiation (PAR) [10]. Photosynthetically active radiation (PAR) intercepted by the crop is transformed in biomass; thus, the lineal relationship among these variables represents radiation use efficiency (RUE) that is expressed in $g$ of dry matter (DM) per $\mathrm{MJ}^{-1}$ 
intercepted [11]. Concerning this aspect, [12] mentioned that, in maize, EUR can vary from 2 to $3.4 \mathrm{~g}$ per $\mathrm{MJ}^{-1}$ depending on the genotype, physiological stage, sowing density, and region. On the other hand, [13] mentions that high population densities on maize intercept higher amounts of radiation increasing significantly biomass production up to $1400 \mathrm{gm}^{-2}$ influencing determinately the final grain yield. Concerning managing practices on the crop, [14] suggests that this have influence on the yield of corn. Population density allows for having anticipated higher canopy in the crop, favoring biomass production. Population density affects efficiency on use of radiation and vegetative and reproductive process of corn growth and directly influences the use of agricultural inputs (water, varieties, and nutrients) [15]. Concerning the final number of grains on ear, it is established that this variable is in close relationship with yield, as it has been demonstrated by the high correlation coefficients between both variables [16]. In this study, six cultivars were evaluated during three years $(2008,2009$, and 2010) under three population densities aiming to assess the radiation use efficiency, intercepted radiation, biomass production, and grain yield. Results will help to define the best cultivar for the studied region.

\section{Materials and Methods}

This study was performed at Toluca, Mexico, $19^{\circ} 24^{\prime} \mathrm{N}$, $99^{\circ} 54^{\prime} \mathrm{W}$, at 2611 masl. Climate is mild temperate $\left[\mathrm{Cw}_{1}\left(\mathrm{w}^{\prime}\right) \mathrm{eg}\right]$, with a rain period from June to September and dry winters. Rainfall ranges from 800 to $1250 \mathrm{~mm}$ and annual average temperature is $12^{\circ} \mathrm{C}$, ranging from 7 to $14^{\circ} \mathrm{C}$. The warmest month corresponds to May, before summer solstice [17]. Soil is vertisol type in formation process [pH = 6,6; $0,30 \mathrm{~m}$ depth; $2,6 \%$ organic matter; initial phosphorous level of $5,8 \mathrm{mg} / \mathrm{kg}$ according to Bray and Kurtz method, and cation-exchange capacity (CEC) of $14,5 \mathrm{Cmol}(+) \mathrm{kg}^{-1}$ of air-dried soil]. Three open pollinated corn land races ("Amarillo," "Cacahuacintle," and "Iiquipilco") and three hybrids recommended for this region of intermediate growing cycle (90-100 days to male flowering), "Z-60" (single cross hybrid), "Condor" (three-line hybrid), and "H-50" (double cross hybrid) [18], were evaluated. Sowing was performed by hand on April 9, 2008; April 10, 2009; and April 17, 2010. Three seeds were placed per hole. Plants were thinned at the stage of four leaves, leaving one plant per hole. Topological arrangement to get desired density for each treatment $\left(6.9,7.8\right.$, and 8.9 plants $\left.\mathrm{m}^{-2}\right)$ was 18 , 16 , and $14 \mathrm{~cm}$ between plants, respectively. Data analysis was under a factorial design on split plots. Main plots were population densities $\left(6.9,7.8\right.$, and 8.9 plants $\left.\mathrm{m}^{-2}\right)$ and smaller plots were cultivars ("Amarillo," "Cacahuacintle," "Tiquipilco," "Z-60," "Condor," and "H-50"). Treatments were distributed by a randomized blocks design with three replications. Experimental units were five rows $5 \mathrm{~m}$ long with $80 \mathrm{~cm}$ between rows. Useful plot was integrated by the three central rows. At sowing, fertilizer was applied with the formula 90-90-46 applying urea, calcium triple superphosphate, and potassium chloride, respectively, and other $90 \mathrm{Kg} \mathrm{N} \mathrm{Ha}^{-1}$ (urea) were applied at hilling, 40 days after sowing. Experiments were established with watering at sowing; crop fulfilled its water requirements with rainfall. Evaluated variables were as follows: (1) For leaf area (LA), on each treatment, 5 plants were removed at male flowering, leaves were measured with a leaf area meter Li-Cor 3100, and average was determined and expressed in $\mathrm{cm}^{-2}$, (2) Leaf area index (LAI) was determined by the formula: (LA)(PD)/SA, where PD is planting density and SA is sown area [19]. (3) For number of grains $\left(\mathrm{NG}, \mathrm{m}^{-2}\right)$, at harvest, measured on 10 ears, grains were counted and an average per ear was obtained. (4) Grain yield (Yield $\mathrm{gm}^{-2}$ ) is the average weight of grain (14\% moisture) from 10 ears. From the weather station of Agricultural Sciences Faculty, Mexico State Autonomous University, located on the studied area, data on maximum, minimum, and average temperature, rainfall, and incident global radiation (IGR) were registered during the experiment period. Intercepted radiation IR expressed in percentage was measured at male flowering on each treatment with a sensor Li-Cor 191. This variable was measured at solar noon at soil level. Radiation use efficiency (RUE) was expressed as $\mathrm{g} \mathrm{MJ}^{-1}$ and obtained through formula: RUE $=($ YIELD/PAR $)($ IR $)$ being YIELD.

\section{Results and Discussions}

Table 1 shows ANOVA for years, population densities, and cultivars. Highly significant differences were detected for year factor concerning biomass, radiation use efficiency (RUE), and yield, while for LAI and number of grains (NG) only significant differences were detected. In relation to factors population density and cultivars, all variables exhibited highly significant differences except for leaf area index. Concerning the interaction of studied factors, years with densities were highly significant for RUE. For interaction year with cultivar, highly significant differences were detected for K, NG, RUE, and yield. Variation coefficient ranged from 6.4 to $19.1 \%$. Best growing cycle was 2008 with an average yield of $1132.6 \mathrm{~g} \mathrm{~m}^{-2}$, surpassing years 2009 and 2010 by 14.1 and $16.3 \%$, respectively. This result is attributed to higher average on the variables biomass $3505.9 \mathrm{~g} \mathrm{~m}^{-2}$ and to RUE of $0.79 \mathrm{~g} \mathrm{MJ}^{-1}$, having highest values concerning LAI, $\mathrm{k}$, and GN with values of $3.6,86.1 \%$, and 2824 grains $\mathrm{m}^{-2}$, respectively. During 2008 highest rainfall was registered, compared with other evaluated years and plants exhibited the highest leaf area and, thus, the highest number of grains, but not on dry matter of grain due to higher distribution of photo assimilates to caryopsides. Concerning the grain yield, the highest was for 2008 with $1132.6 \mathrm{~g} \mathrm{~m}^{-2}$, excelling years 2009 and 2010. This is attributed to the fact that, on these years, due to the low rainfall, plant distributed carbohydrates to the grain. This factor also affected LAI, IR, and K. Concerning the population densities, higher density (8.9 plants $\mathrm{m}^{-2}$ ) exhibited the highest values for LAI, IR, K, GN biomass, yield, and RUE with 3.82, 88.6\%, $0.66,346.9 \mathrm{~g} \mathrm{~m}^{-2}$, $3476.6 \mathrm{~g} \mathrm{~m}^{-2}$, and $0.68 \mathrm{~g} \mathrm{~m}^{-2} \mathrm{MJ}^{-1}$, respectively. These values were expected because, increasing the number of plants per area, the values of studied variables increase. With a higher LAI, more solar radiation is captured, and more biomass 
TABLE 1: Analysis of variance and mean separation densities of three to six maize cultivars evaluated in years 2008, 2009 , and 2010.

\begin{tabular}{|c|c|c|c|c|c|c|c|c|}
\hline Factor & LAI & IR (\%) & K & $\mathrm{GN} \mathrm{m}^{-2}$ & $\begin{array}{c}\text { Biomass } \\
\mathrm{g} \mathrm{m}^{-2}\end{array}$ & $\begin{array}{l}\text { Yield } \\
\mathrm{g} \mathrm{m}^{-2}\end{array}$ & $\begin{array}{c}\text { RUE } \\
\left(\mathrm{g} \mathrm{MJ}^{-1}\right)\end{array}$ & $\mathrm{HI}$ \\
\hline Years $(Y)$ & * & NS & NS & * & $* * *$ & $* * *$ & $* * *$ & NS \\
\hline 2008 & $3.3^{\mathrm{b}}$ & $85.1^{\mathrm{a}}$ & $0.64^{\mathrm{a}}$ & $2588.1^{\mathrm{b}}$ & $3505.9^{\mathrm{a}}$ & $1132.6^{\mathrm{a}}$ & $0.79^{\mathrm{a}}$ & $0.323^{\mathrm{a}}$ \\
\hline 2009 & $3.6^{\mathrm{a}}$ & $86.1^{\mathrm{a}}$ & $0.62^{\mathrm{a}}$ & $2824^{\mathrm{a}}$ & $2784.7^{\mathrm{b}}$ & $951.4^{\mathrm{b}}$ & $0.51^{\mathrm{c}}$ & $0.342^{\mathrm{a}}$ \\
\hline 2010 & $3.5^{\mathrm{ab}}$ & $85.6^{\mathrm{a}}$ & $0.63^{\mathrm{a}}$ & $2706^{\mathrm{ab}}$ & $2909.1^{\mathrm{b}}$ & $964.1^{\mathrm{b}}$ & $0.54^{\mathrm{b}}$ & $0.333^{\mathrm{a}}$ \\
\hline $\mathrm{DSH}_{0.05}$ & 0.21 & 3.33 & 0.033 & 158.3 & 233.7 & 59.1 & 0.033 & 0.0439 \\
\hline Density $(D)$ & $* * *$ & $* * *$ & $* * *$ & $* * *$ & $* * *$ & $* * *$ & $* * *$ & NS \\
\hline 6.9 plants $\mathrm{m}^{2}$ & $2.95^{\mathrm{C}}$ & $81.83^{\mathrm{b}}$ & $0.60^{\mathrm{b}}$ & $2382.8^{c}$ & $2687.6^{c}$ & $931.8^{c}$ & $0.54^{\mathrm{c}}$ & $0.351^{\mathrm{a}}$ \\
\hline 7.8 plants $\mathrm{m}^{2}$ & $3.55^{\mathrm{b}}$ & $86.32^{\mathrm{a}}$ & $0.62^{\mathrm{b}}$ & $2688.4^{\mathrm{b}}$ & $3114.6^{\mathrm{b}}$ & $992.1^{\mathrm{b}}$ & $0.58^{\mathrm{b}}$ & $0.333^{\mathrm{a}}$ \\
\hline 8.9 plants $\mathrm{m}^{2}$ & $3.82^{\mathrm{a}}$ & $88.59^{\mathrm{a}}$ & $0.66^{\mathrm{a}}$ & $3046.9^{a}$ & $3397.7^{\mathrm{a}}$ & $1150.2^{\mathrm{a}}$ & $0.68^{\mathrm{a}}$ & $0.349^{\mathrm{a}}$ \\
\hline $\mathrm{DSH}_{0.05}$ & 0.211 & 3.33 & 0.032 & 158.3 & 233.5 & 59.1 & 0.033 & 0.038 \\
\hline Cultivars $(C)$ & $* * *$ & $* *$ & $* * *$ & $* * *$ & $* * *$ & $* * *$ & $* * *$ & NS \\
\hline "Jiquipilco" & $3.8^{\mathrm{a}}$ & $86.42^{\mathrm{ab}}$ & $0.66^{\mathrm{b}}$ & $2768^{\mathrm{ab}}$ & $3390.8^{\mathrm{ab}}$ & $1156.1^{\mathrm{a}}$ & $0.67^{\mathrm{a}}$ & $0.341^{\mathrm{a}}$ \\
\hline "Amarillo Almoloya" & $3.12^{\mathrm{c}}$ & $85.02^{\mathrm{b}}$ & $0.61^{\mathrm{c}}$ & $3022^{\mathrm{a}}$ & $3003.2^{\mathrm{b}}$ & $1052^{\mathrm{ab}}$ & $0.62^{\mathrm{ab}}$ & $0.361^{\mathrm{a}}$ \\
\hline "Cacahuacintle" & $3.75^{\mathrm{a}}$ & $89.2^{\mathrm{a}}$ & $0.70^{\mathrm{a}}$ & $2139^{c}$ & $3646.8^{\mathrm{a}}$ & $964.9^{\mathrm{bc}}$ & $0.60^{\mathrm{bc}}$ & $0.264^{\mathrm{a}}$ \\
\hline "Condor" & $3.28^{\mathrm{bc}}$ & $84.2^{\mathrm{b}}$ & $0.59^{\mathrm{cd}}$ & $2889^{\mathrm{a}}$ & $2947.30^{\mathrm{b}}$ & $1021.7^{\mathrm{bc}}$ & $0.57^{\mathrm{bc}}$ & $0.347^{\mathrm{a}}$ \\
\hline “H-50” & $3.70^{\mathrm{ab}}$ & $89.9^{\mathrm{a}}$ & $0.61^{\mathrm{cd}}$ & $2898^{\mathrm{a}}$ & $2980.1^{\mathrm{b}}$ & $990.1^{\mathrm{bc}}$ & $0.58^{\mathrm{bc}}$ & $0.332^{\mathrm{a}}$ \\
\hline “Z-60” & $3.04^{c}$ & $83.5^{\mathrm{b}}$ & $0.58^{\mathrm{d}}$ & $2518^{\mathrm{b}}$ & $2431.9^{c}$ & $936.7^{c}$ & $0.55^{\mathrm{c}}$ & $0.389^{\mathrm{a}}$ \\
\hline $\mathrm{DSH}_{0.05}$ & 0.43 & 4.70 & 0.034 & 346.2 & 475.3 & 90.34 & 0.051 & 0.521 \\
\hline$Y * D$ & ns & ns & ns & ns & ns & ns & $* * *$ & ns \\
\hline$Y * C$ & ns & ns & $* *$ & $* *$ & ns & $* * *$ & $* * *$ & $* *$ \\
\hline$D * C$ & ns & ns & $* *$ & ns & $* *$ & $* *$ & $* *$ & ns \\
\hline$Y * D * C$ & ns & ns & ns & ns & * & ns & ns & $* *$ \\
\hline CV\% & 15.7 & 6.9 & 6.41 & 16.1 & 19.1 & 11.2 & 10.8 & 18.8 \\
\hline
\end{tabular}

${ }^{* * *} P \leq 0.001,{ }^{* *} P \leq 0.01,{ }^{*} P \leq 0.05$, and ns: no significant difference. Columns with the same letter in each study factor are statistically equal $(P \leq 0.05) ; \mathrm{HSD}$ : honest significant difference; CV: coefficient of variation; LAI: leaf area index; IR: intercepted radiation; $K$ : light attenuation coefficient; GN: grain number; EUR: efficiency in the use of radiation; HI: harvest index.

is produced, increasing the number of grains per area and so yield is increased and also RUE. Regarding the cultivars, "Jiquipilco" exhibited the highest LAI, yield, and RUE with $3.8,1156.1 \mathrm{~g} \mathrm{~m}^{-2}$, and $0.67 \mathrm{~g} \mathrm{~m}^{-2} \mathrm{MJ}^{-1}$, respectively. On the other hand, Z-60 exhibited minimum values for LAI, yield, and RUE. These results indicate that "Jiquipilco" (having higher genetic variability because of its open pollination origin) exhibits more phenotypic resilience. "Jiquipilco" is well adapted to ecological conditions of the studied region; Z-60, on other hand, has been created for Bajio (low lands) Mexican zone, where temperature and rainfall contrast with those of the Mexican high plateau. This response differs from that reported by [20], who mentioned that maize yield under conditions of Kenya to rotate the crop with legumes was $7.0 \mathrm{tha}^{-1}, 38 \%$ lower than those reported in this study may be due to the different areas where the studies were conducted.

Figure 1 shows that higher yield was produced by open pollinated genotypes "Jiquipilco" and "Amarillo" during the three evaluated growing cycles. This is attributed to its higher plasticity to heavy rainfalls, which produce flooding and that, in the case of hybrids, induces chlorosis. Hybrids were affected by soil flooding at both vegetative and reproductive stage [21].

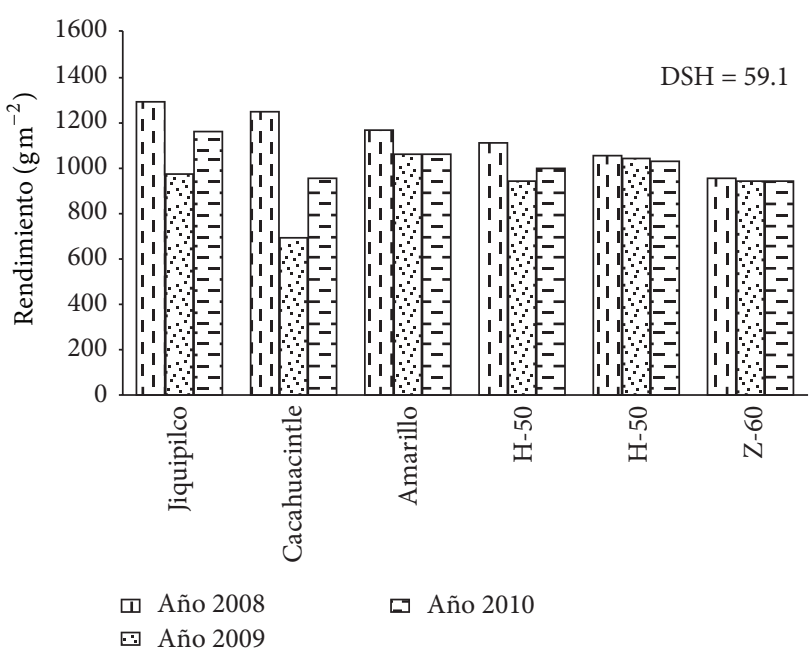

Figure 1: Corn grain yield of six cultivars under three planting densities. El Cerrillo, Toluca México Summer 2008, 2009, and 2010.

"Amarillo" creole was the most homogeneous in three years, exhibiting the following yields $\left(1160 \mathrm{~g} \mathrm{~m}^{-2}\right.$ in 2008 , 


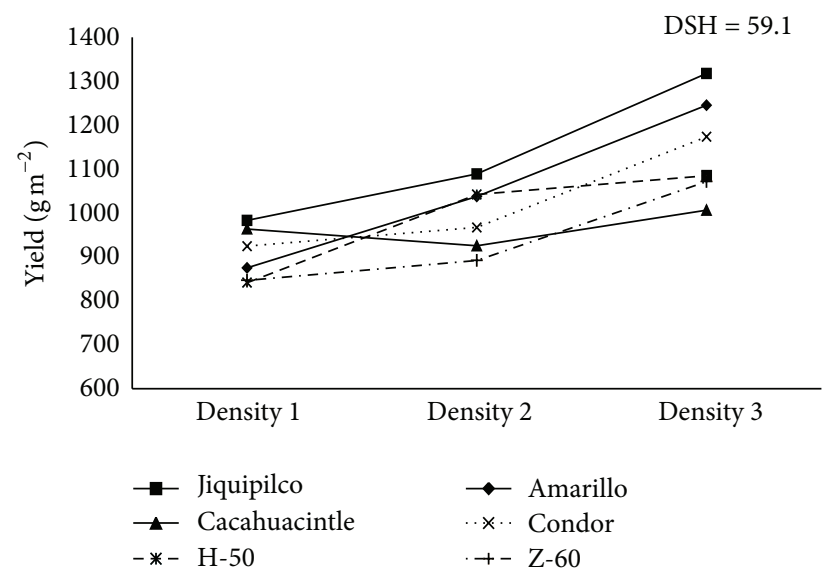

FIGURE 2: Interaction yield versus plant density evaluated at 2008, 2009, and 2010 summer. El Cerrillo, Toluca Mexico. Densities 1, 2, and $3=6.9,7.8$, and 8.9 plants $\mathrm{m}^{-2}$, respectively.

$1054.9 \mathrm{~g} \mathrm{~m}^{-2}$ in 2009 , and $1052 \mathrm{~g} \mathrm{~m}^{-2}$ in 2010). Hybrids exhibited a consistent performance outstanding "Condor" with yields of 1049, 1033, and $1021 \mathrm{~g} \mathrm{~m}^{-2}$ for 2008, 2009 [22], and 2010, respectively. Similar results are reported by [8].

Figure 2 exhibits interaction population density with yield, showing that the highest yield was for open pollinated cultivars such as "Jiquipilco" and "Yellow." When population density was increased from 2 to 3 , yields were increased from 1088 to $1317 \mathrm{~g} \mathrm{~m}^{-2}$ for "Jiquipilco," while for "Yellow" increased from 1037 to $1245 \mathrm{~g} \mathrm{~m}^{-2}$. Concerning hybrids, "Condor" and "Z-60" exhibited a similar pattern concerning response to population density. "Condor" exhibited an increase from 967 to $1173 \mathrm{~g} \mathrm{~m}^{-2}$ while Z-60 increased from 891 to $1071 \mathrm{~g} \mathrm{~m}^{-2}$. The aforementioned results indicate that open pollinated genotypes respond well to population density increases and that are well suited to agroecological conditions of studied area; this response is exhibited only for hybrids "Z-60" and "Condor." Higher genetic variability of creoles allows phenotypic plasticity, and, so, yield increases with high population densities, despite the intraspecific competition.

This response has been corroborated by [20]; they mention that creole genotypes, particularly indigenous, exhibit high genetic variability that gives them an inherent capacity of adaptation to variable agroecological conditions of the region, generating good yields and good quality attributes on sweet corn and grain. Hybrids lack those attributes and so their performance is not so good [21-23]. Note that, in hybrids such as $\mathrm{H}-143 \mathrm{C}$ and $\mathrm{H}-149 \mathrm{C}$, increase in population density affects significantly chemical composition and yield.

\section{Conclusions}

The best cycle was 2008, which has the highest grain yield, biomass, RUE, LAI, IR, and light attenuation coefficient. Regarding the density factor, the highest density 8.9 plants $\mathrm{m}^{-2}$ yielded the highest values for LAI, IR, K, and number of grains. The cultivate "Jiquipilco" presented the highest values of LAI, grain yield and EUR. Of the six cultivars evaluated, it is recommended for use in the study area, which showed a better adaptation with values of population density of 8.9 plants $\mathrm{m}^{-2}$.

\section{Competing Interests}

The authors declare that they have no competing interests.

\section{References}

[1] C. Y. Arellanes and F. A. Casas, "Traditional markets Tehuacan Valley-Cuicatlán: background and current situation," New Anthropology, vol. 24, no. 74, pp. 93-123, 2011.

[2] M. Valdez-Morales, K. Barry, G. C. Fahey Jr. et al., "Effect of maize genotype, developmental stage, and cooking process on the nutraceutical potential of huitlacoche (Ustilago maydis)," Food Chemistry, vol. 119, no. 2, pp. 689-697, 2010.

[3] M. A. Asturias, Maize Sacred Food to Hungry Business, vol. 111, IVOS, Quito, Ecuador, 2004.

[4] R. A. Rivetti, "Maize production under different regimes of supplemental irrigation in Rio Cuarto, Argentina Códova II. Dry matter production," Revista de la Facultad de Ciencias Agrarias, vol. 38, no. 2, pp. 25-36, 2007.

[5] P. J. D. O. P. de Souza, A. Ribeiro, E. J. P. da Rocha et al., "Solar radiation use efficiency by soybean under field conditions in the Amazon region," Pesquisa Agropecuaria Brasileira, vol. 44, no. 10, pp. 1211-1218, 2009.

[6] R. C. Muchow, M. J. Robertson, and B. C. Pengelly, "Radiationuse efficiency of soybean, mungbean and cowpea under different environmental conditions," Field Crops Research, vol. 32, no. 1-2, pp. 1-16, 1993.

[7] E. A. Lee and M. Tollenaar, "Physiological basis of successful breeding strategies for maize grain yield," Crop Science, vol. 47, no. 3, pp. S202-S215, 2007.

[8] A. Morales-Ruiz, R. E. J. Morales, M. O. Franco, B. D. Mariezcurrena, C. G. Estrada, and M. T. H. Norman, "Maize population density, light attenuation coefficient and performance," Revista Mexicana de Ciencias Agrícolas, vol. 8, pp. 14251431, 2014.

[9] G. A. Maddonni and M. E. Otegui, "Leaf area, light interception, and crop development in maize," Field Crops Research, vol. 48, no. 1 , pp. 81-87, 1996.

[10] L. E. Díaz, R. E. Morales, M. O. Franco, and L. A. Domínguez, "Attenuation coefficient of light intercepted radiation, biomass and yield of maize in function of phosphorus," Terra Latinoamericana, vol. 29, pp. 65-74, 2011.

[11] T. R. Sinclair and R. C. Muchow, "Radiation use efficiency," Advances in Agronomy, vol. 65, pp. 215-265, 1999.

[12] C. J. Birch, G. L. Hammer, and K. G. Rickert, "Dry matter accumulation and distribution in five cultivars of maize (Zea mays): relationships and procedures for use in crop modelling," Australian Journal of Agricultural Research, vol. 50, no. 4, pp. 513-527, 1999.

[13] C. Giménez, D. J. Connor, and F. Rueda, "Canopy development, photosynthesis and radiation-use efficiency in sunflower in response to nitrogen," Field Crops Research, vol. 38, no. 1, pp. 15-27, 1994.

[14] F. H. Andrade, L. Echarte, R. Rizzalli, A. Della Maggiora, and M. Casanovas, "Kernel number prediction in maize under nitrogen or water stress," Crop Science, vol. 42, no. 4, pp. 1173-1179, 2002. 
[15] J. L. Cárcova, G. Abeled, and M. P. López, "Analysis generation yield, partition and components," in Cereal Products, Functional Basis for Management, H. E. Satorre, B. R. L. Arnold, A. G. Slafer et al., Eds., Editorial Facultad de Agronomía, pp. 74-98, Universidad de Buenos Aires, Buenos Aires, Argentina, 2004.

[16] E. M. Otegui and F. H. Andrade, "New relationships between light interception, ear growth and kernel set in maize," in Physiology and Modeling of Kernel Set in Maize, M. E. Westgate and K. Boote, Eds., Crop Science Society of America, American Society of Agronomy Special Publication No. 29, chapter 6, pp. 89-102, EE UU, Baltimore, Md, USA, 2000.

[17] E. García, Amendments to the Köppen Climate Classification System, Talleres Larios, México City, México, 2005.

[18] K. L. Tully, S. A. Wood, M. Almaraz, Ch. Neill, and Ch. Palm, "The effect of mineral and organic nutrient input on yields and nitrogen balances in western Kenya," Agriculture, Ecosystems \& Environment, vol. 214, pp. 10-20, 2015.

[19] H. A. González, C. J. Sahagún, L. D. Pérez et al., "Cacahuacintle phenotypic diversity of maize in the valley of Toluca, Mexico," Revista Fitotecnia Mexicana, vol. 29, pp. 255-261, 2007.

[20] R. R. Durán, J. Sahag, and C. J. Sahagún, "The geneenvironment interaction in plant breeding," Revista Chapingo, vol. 16, pp. 13-16, 1992.

[21] R. A. Contreras, R. C. G. Martínez, and C. G. Estrada, "Efficiency in the use of radiation by maize hybrids highlands of Mexico," Fitotecnia Mexicana, vol. 35, pp. 161-169, 2012.

[22] E. Ortiz-Torres, P. A. López, A. Gil-Muñoz et al., "Yield and quality of tender maize from native maize populations of Tehuacán, Puebla," Revista Chapingo. Serie Horticultura, vol. 19, no. 2, pp. 225-238, 2013.

[23] C. G. Vázquez, M. A. Mejía, H. M. Y. Salinas, and R. D. Santiago, "Effect of population density on the quality of grain, masa and tortilla corn hybrids with high quality protein," Revista Fitotecnia Mexicana, vol. 36, no. 3, pp. 225-232, 2013. 


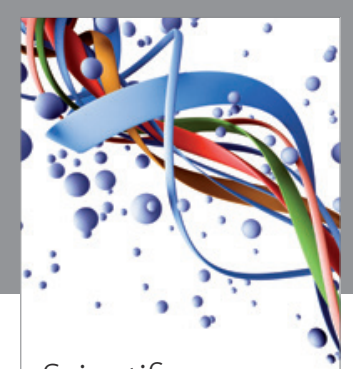

Scientifica
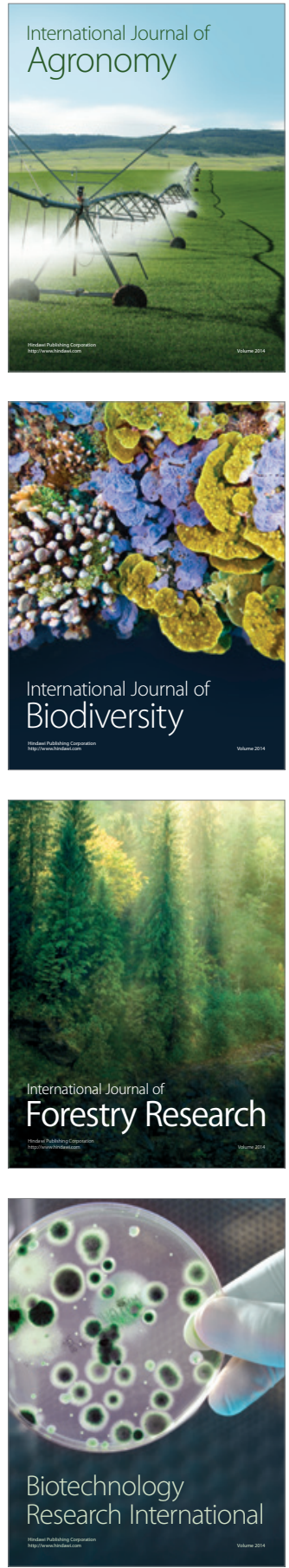
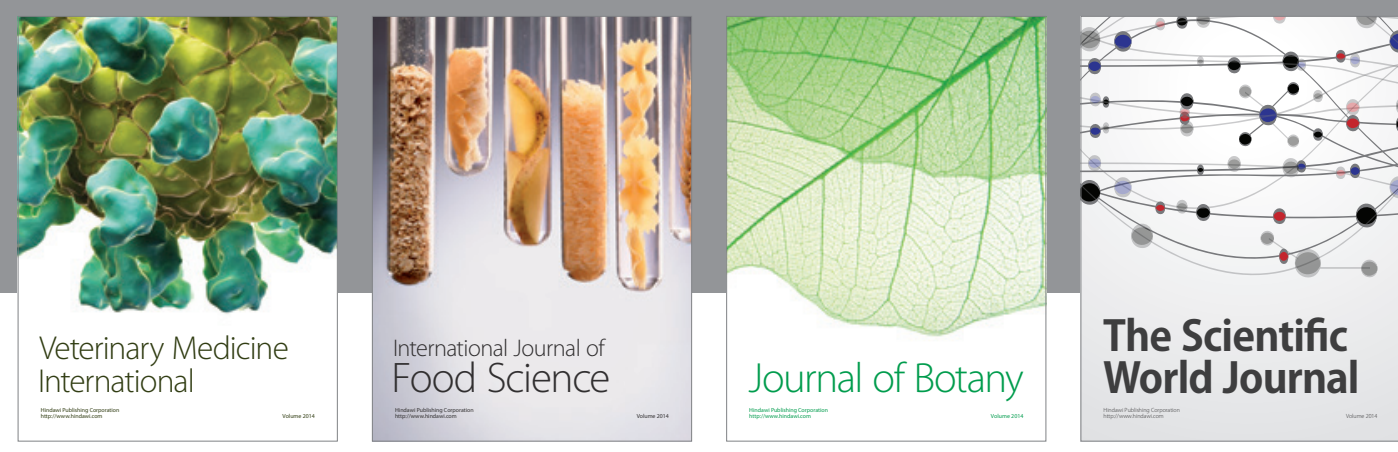

The Scientific

\section{World Journal}

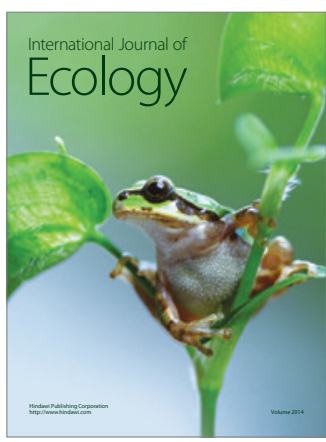

\section{Hindawi}

Submit your manuscripts at

http://www.hindawi.com
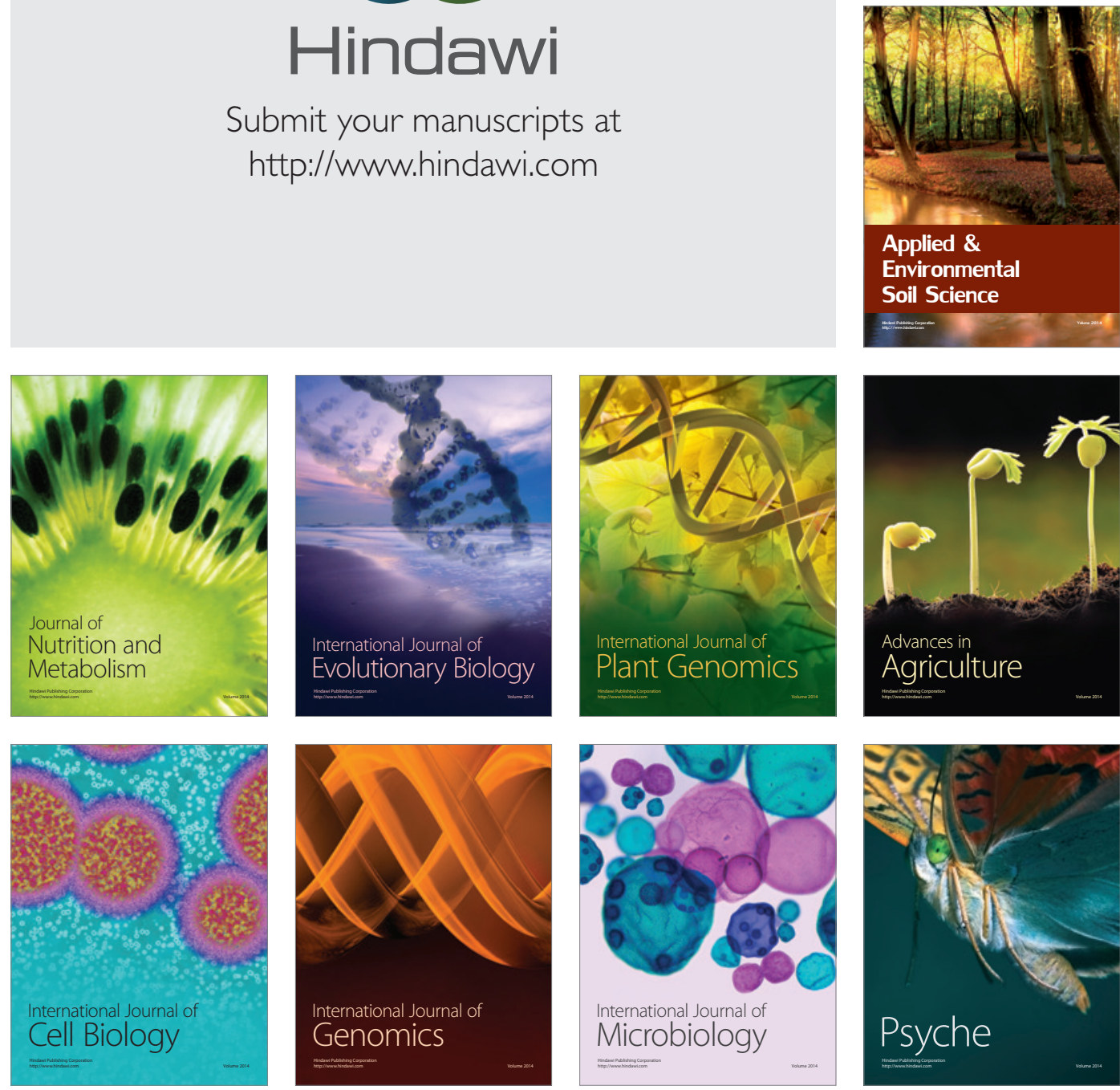
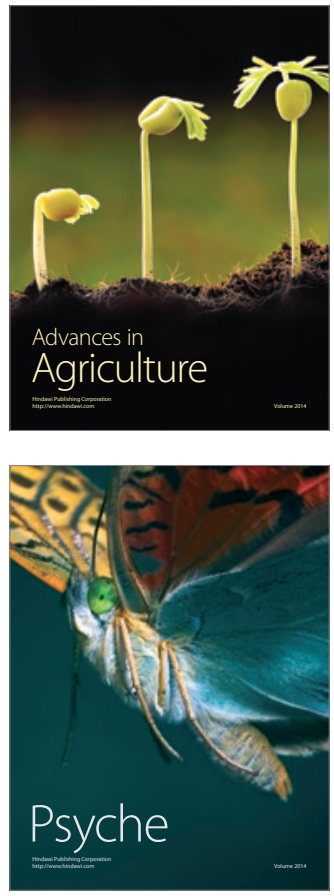